\title{
Pemahaman Muzakki Tentang Zakat Maal (Studi Kasus Masjid Al-Magfirah Kelurahan Karame Kecamatan Singkil Kota Manado)
}

\author{
Oleh: Siska Zakaria
}

\begin{abstract}
ABSTRAK
Tulisan ini berkenaan dengan pemahaman muzakki mengenai zakat maal masjid AlMagfirah Kelurahan Karame Kecamatan Singkil Kota Manado. Zakat merupakan salah satu rukun Islam yang selalu disebutkan sejajar dengan shalat. Inilah yang menunjukkan betapa pentingnya zakat dalam Islam. Oleh karenanya zakat merupakan salah satu syari'at Islam yang harus dijalankan, maka zakat sangat ditekankankan kepada orang-orang yang beriman sebagai upaya peningkatan iman dan takwa kepada Allah swt. Banyak polemik yang terjadi dalam permasalahan zakat ini. Salah satunya adalah ketidak pahaman muzakki akan pentingnya zakat dalam meningkatkan taraf hidup orang muslim yang berada dalam kefakiran dan kemiskinan. Hasil penelitian ini ketidak pahaman muzakki akan zakat maal yang, mengakibatkan pengumpulan dan penerimaan zakat maal tidak maksimal. Akibat akhirnya adalah tujuan zakat maal yang diamanahkan oleh ajaran Islam tidak tercapai. Akhirnya jumlah fakir dan miskin akan semakin bertambah dari tahun ke tahun dan mustahik akan berkurang. Maka penulis menyimpulkan bahwa, jama'ah masjid Al-Magfirah Kelurahan Karame belum memahami apa yang disebut zakat maal. Karena dari 8 orang yang wajib mengeluarkan zakat hanya 2 Orang mengeluarkan zakat maal itupun tidak sesuai dengan jenis harta apa yang dikeluarkan.
\end{abstract}

\section{PENDAHULUAN}

\section{A. Latar Belakang}

Zakat merupakan salah satu kewajiban bagi umat Islam yang telah ditetapkan dalam AlQur'an, sunnah Nabi, Ijma' para ulama. Zakat merupakan salah satu rukun Islam yang selalu disebutkan sejajar dengan shalat. Inilah yang menunjukkan betapa pentingnya zakat dalam Islam. Bagi mereka yang mengingkari kewajiban zakat maka telah kafir, begitu juga mereka yang melarang adanya zakat secara paksa. Jika ada yang menentang adanya zakat harus di bunuh hingga mau melaksanakannya. ${ }^{1}$

\footnotetext{
${ }^{1}$ Abdul Al-Hamid Mahmud Al-Ba'ly, Ekonomi Zakat (Jakarta: PT Raja Grafindo Persada, 2006), h. 1.
} 
Kondisi yang seperti ini memberikan inspirasi kepada setiap muslim yang mampu untuk mensejahterakan saudara muslim yang mampu dapat dikatakan bahwa zakat bukan hanya sebagai sarana untuk mendekatkan diri kepada Allah swt., atau sekedar masalah kewajiban semata akan tetapi zakat dapat memberi manfaat melalui zakat yang dikeluarkannya.

Meskipun begitu, masih banyak umat Islam yang kurang bahkan tidak memahami tentang zakat, sehingga tidak sedikit masalah yang ditimbulkan tentang pembagian zakat dan pengumpulan zakat. Sebagian orang mengeluarkan zakat tidak lebih dari sekedar menggugurkan kewajiban. Kurangnya pehamahaman tentang zakat ini juga yang menjadi penyebab, sebagian umat Islam merasa berat untuk mengeluarkan zakat, terutama zakat maal, disamping itu juga kurangnya pengetahuan tentang keutamaan-keutamaan zakat.

Meninjau kembali dengan banyaknya polemik yang terjadi dalam persoalan zakat, khusunya pada zakat maal. Zakat maal adalah zakat pembersihan harta yang di keluarkan apabila sudah sampai nisab dan haul. Zakat maal juga mempunyai fungsi dalam kehidupan. Pertama, zakat maal merupakan pembersihan harta. Kedua, pemberantasan kemiskinan. Ketiga, pembagian rezeki sesama muslim, dan yang ke empat, bantuan usaha sesama muslim.

Di Kelurahan Karame, tersebut terlihat pada muzakki masjid Al-Magfirah, pemahaman zakat maal masih minim sebab kenyataan masih banyak yang menganggap zakat maal hanya seperti sedekah dan infak, jadi tidak akan meningkat penerimaan zakat maal jika muzakki mengangap seperti itu.

Sesuai dengan observasi awal penulis di lapangan hanya dua orang yang mengeluarkan zakat maal, sedangkan masih banyak orang yang mampu mengeluarkan zakat maal tidak mengeluarkan zakat maal karena menganggap zakat maal itu hampir sama dengan sedekah maupun pajak padahal tidak demikian zakat maal yang dimaksud. Dan juga ada yang mengeluarkan zakat maal nya pada bulan Ramadhan sekaligus dengan zakat fitrah dan hal ini tidak tahu apa yang dikeluarkan itu adalah zakat maal atau bukan. ${ }^{2}$

\section{B. Rumusan Masalah}

Mengacu pada permasalahan di atas, penulis merumuskan masalah pokok yang akan menjadi pembahasan dalam skrpsi ini yaitu pemahaman muzakki tentang zakat maal dan peningkatan dari zakat maal itu sendiri

\footnotetext{
${ }^{2}$ Data penyetoran zakat maal jama'ah Masjid al-Magfirah pada bulan Ramadhan tahun 2013.
} 
Dari rumusan masalah tersebut penulis menyusun beberapa batasan masalah agar pembahasan lebih rinci dan terarah:

1. Bagaimana pemahaman muzakki masjid Al-Magfirah tentang zakat maal?

2. Apakah pemahaman muzakki masjid Al-Magfirah dapat meningkatkan penerimaan zakat maal?

\section{TINJAUAN KEPUSTAKAAN}

\section{A. Zakat Secara Umum}

Zakat adalah bagian hak Allah swt. yang diberikan oleh manusia kepada orang-orang miskin. Dinamakan zakat, karena mengandung harapan mendapat berkah, penyucian diri dan tambahan kebaikan. Allah swt. Kata dasarnya adalah Az-zaka yang berarti berkembang suci dan berkah. $^{3}$

Allah swt.. Berfirman dalam Q.S. At-Taubah/9: 103

Terjemahnya :

"Ambillah zakat dari sebagian harta mereka, dengan zakat itu kamu membersihkan dan mensucikan mereka dan mendoalah untuk mereka. Sesungguhnya doa kamu itu (menjadi) ketenteraman jiwa bagi mereka. dan Allah Maha mendengar lagi Maha mengetahui" . ${ }^{4}$

Dalam hadis Sahih Bukhari-Muslim dan yang lain-dari ibnu Abbas, bahwa Nabi SAW ketika mengutus Mu'az ke yaman, beliau berkata :

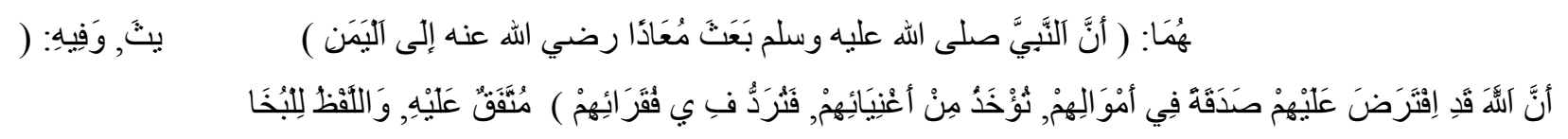

${ }^{3}$ Sayyid Sabiq, Fiqhus Sunnah, terj. Asep Sobari, dkk, Fiqh Sunnah jilid II Cet. IV (Jakarta Timur: AlI'tishom Cahaya Umat, 2008), h. 487.

${ }^{4}$ Departemen Agama RI, Al-Qur'an dan Terjemahan (Jakarta: Pelita IV, 1984), h. 297. 
Terjemahnya :

Dari Ibnu Abbas r. bahwa Nabi Shallallaahu 'alaihi wa Sallam mengutus Mu'adz ke negeri Yaman --ia meneruskan hadits itu-- dan didalamnya (beliau bersabda): "Sesungguhnya Allah telah mewajibkan mereka zakat dari harta mereka yang diambil dari orang-orang kaya di antara mereka dan dibagikan kepada orang-orang fakir di antara mereka." Muttafaq Alaihi dan lafadznya menurut Bukhari. ${ }^{5}$

\section{B. Zakat Maal}

\section{Pengertian Zakat Maal}

Zakat maal (harta), seperti emas, perak, binatang, tumbuh-tumbuhan dan barang perniagaan (barang dagangan). ${ }^{6}$ Zakat maal, seperti namanya, dikeluarkan oleh setiap umat Islam yang memiliki harta seperti yang tersebut di atas, untuk membersihkan hartanya.

2. Syarat Mengeluarkan Zakat Maal

Sesuatu yang dimiliki manusia yang berharga di sebut kekayaan. keadilan yang diajarkan oleh Islam dan prinsip keringanan yang terdapat di dalam ajaran-ajarannya tidak mungkin akan membebani orang-orang yang terkena kewajiban itu melaksanakannya ke dalam kesulitan yang oleh Tuhan sendiri tidak inginkanNya. Oleh karena itu mestilah batasan tentang sifat kekayaan yang wajib zakat dan syarat-syaratnya adalah:
a. Milik Penuh
b. Lebih dari Kebutuhan Biasa
c. Bebas dari Hutang

3. Jenis-jenis harta yang wajib dizakati

Adapun Jenis harta yang wajib dizakati yaitu:

a. Hewan ternak: unta, sapi dan kambing

b. Hasil pertanian dan buah-buahan: makanan pokok.

c. Zakat Naqd (Emas dan Perak)

${ }^{5}$ Lihat Muhammad Nashirudin Al-albani.,Ringkasan Shahih Muslim, (Jakarta: Pustaka Azzam anggota IKAPIDKI,2003) h. 365, Bandingkan Al hafizd Imam Ibnu Hajar Al- Asqolani, Bulughul Maram 1429 H / 2008 M (Kata: Pustaka Al-Hidayah), no hadist 621.

${ }^{6}$ Ibid., h. 9. 
d. Zakat Perniagaan (Tijarah)

e. Zakat barang tambang (Ma'dan) dan Rikaz

\section{Golongan Penerima Zakat}

Orang-orang boleh menerima zakat terbagi atas delapan golongan, sebagai mana yang telah diterangkan dalam Al-Qur'an, dengan FirmanNya dalam Q.S. At.Taubah/9: 58-59

Terjemahnya:

Dan di antara mereka ada orang yang mencelamu tentang (distribusi) zakat; jika mereka diberi sebahagian dari padanya, mereka bersenang hati, dan jika mereka tidak diberi sebahagian dari padanya, dengan serta merta mereka menjadi marah. Jikalau mereka sungguh-sungguh ridha dengan apa yang diberikan Allah dan RasulNya kepada mereka, dan berkata: "Cukuplah Allah bagi Kami, Allah akan memberikan sebagian dari karuniaNya dan demikian (pula) Rasul-Nya, Sesungguhnya Kami adalah orang-orang yang berharap kepada Allah," (tentulah yang demikian itu lebih baik bagi mereka). ${ }^{7}$

Dan Firman Allah dalam Q.S. At-Taubah/9: 60

Terjemahannya:

"Sesungguhnya zakat-zakat itu, hanyalah untuk orang-orang fakir, orang-orang miskin, pengurus-pengurus zakat, Para mu'allaf yang dibujuk hatinya, untuk (memerdekakan) budak, orang-orang yang berhutang, untuk jalan Allah dan untuk mereka yuang sedang dalam perjalanan, sebagai suatu ketetapan yang diwajibkan Allah, dan Allah Maha mengetahui lagi Maha Bijaksana." 8

\footnotetext{
${ }^{7}$ Departeman Agama RI, al-Qur'an dan Terjemahannya (Jakarta, CV.Kathoda, 2005), h. 282.
}

${ }^{8}$ Ibid., h. 264. 
Sebagaimana Allah berfirman didalam kitab Suci Al-Qur'an surat At-Taubah (9) ayat 60, ada 8 golongan yang berhakmenerima zakat yaitu: ${ }^{9}$

1. Fakir, adalah mereka yang tidak berharta dan tidak mempunyai pekerjaan atau usaha tetap guna mencukupi kebutuhan hidupnya (nafkah), sedangkan orang yang menjamin atau menanggung tidak ada.

2. Miskin, adalah mereka yang tidak mencukupi kebutuhan hidupnya, meskipun ia mempunyai pekerjaan atau usaha tetap, tetapi hasil usaha itu belum dapat mencukupi kebutuhannya, dan orang menanggungnya atau menjamin pun tidak ada.

3. Amil, mereka yang ditugaskan atau ditunjuk oleh orang berkuasa (dalam hal ini pemerintah atau imam) untuk mengurus pelaksanaan zakat, baik mengumpulkan maupun membaginya.

4. Muallaf, adalah mereka yang baru masukIslam dan membutuhkan bantuan untuk menyesuaikan diri dengan keadaan barunya atau mereka yang ingin dimantapkan hatinya di dalam Islam, juga mereka yang diharap akan membela orang Islam. Mereka diberi bahagian, agar mereka yakin bahwa agama yang mereka anut adalah agama yang tidak melupakan nasib mereka, atau dengan kata lain bukan agama yang menjanjikan kebahagiaan di hari kemudian saja, tetapi juga menaruh perhatian penuh pada nasib dan kehidupan mereka.

5. Hamba Sahaya, yang ingin memerdekakan dirinya. Mereka yang mempunyai perjanjian dengan majikannya akan dimerdekakan menebus dengan uang. Dari golongan kelima ini, kita dapat kesimpulan yang jelas bahwa agama ini menganjurkan pembebasan budak dan hamba.

6. Gharim, yaitu mereka yang telilit hutang dan belum bisa memenuhi kebutuhan pokoknya. Termasuk ke dalamnya, mereka yang berhutang untuk kemaslahatan sendiri, mereka yang berhutang karena kemaslahatan umum, dan kemaslahatan bersama yang lain, seperti mendamaikan persengketaan, menjamu tamu, memakmurkan masjid, membuat jembatan dan lain-lain.

${ }^{9}$ Direktorat Jendral Pemberdayaan Pembinaan Kelembagaan agama Islam Departemen Agama, Ilmu Fiqh (Jakarta: Proyek Pembinaan Prasarana da Sarana Perguruan Tinggi Agama, 1985). h. 13-14. 
7. Fisabilillah, mereka yang berjuang di jalan Allah, yaitu usaha-usaha yang tujuannya untuk meninggikan syi'ar agama Islam seperti membela dan mempertahankan agama, mendirikan tempat ibadah, pendidikzn dan lembaga-lembaga keagamaan lainnya.

8. Ibnu Sabil, mereka yang kehabisan biaya di perjalanan dan tak dapat mendatangkan belanja dari kampungnya, walaupun ia orang yang berharta di kampungnya.

\section{Pelaku Sistem Pengamalan Zakat}

Zakat merupakan manifestasi dari kegotongroyongan antara orang kaya dengan fakir miskin. Pemberdayaan zakat merupakan perlindungan bagi masyarakat dari bencana kemasyarakatan, yaitu kemiskinan, kelemahan baik fisik maupun mental. Lembaga "zakat" merupakan sarana distribusi kekayaan didalam ajaran Islam yang merupakan kewajiban kolektif perekonomian umat Islam. Zakat merupakan komitmen seorang muslim dalam bidang socialekonomi yang tidak terhindarkan untuk memenuhi kebutuhan pokok bagi semua orang, tanpa harus meletakkan beban pada kas negara semata. ${ }^{10}$

Adapun pelaku sistem zakat ada 3, yaitu Ulul Amri, Umat Islam pada umumnya, dan Organisasi Amil zakat.

1. Ulul Amri (Ulama dan Umara)

Kata "Ulul Amri" menurut bahasa berarti pihak yang mengurusi atau pihak yang memiliki kuasa. Pihak ini bisa perseorangan dan bisa berupa sekelompok orang. ${ }^{11}$

2. Umat Islam pada umumnya

Secara umum, tugas dan kewajiban umat Islam pada umumnya adalah bertekad bulat untuk dapat menunaikan zakat sebagai pengamalan rukun Islam yang ketiga.

3. Amil Zakat

Amil zakat adalah salah satu pelaku zakat yang bertindak sebagai tim atau Organisasi Pelaksana Zakat. Tim inilah yang secara langsung menangani pelaksanaan amaliah zakat.

${ }^{10}$ Ibid., h.92.

${ }^{11}$ M. Nipan Abdul Halim, Mengapa Zakat Disyari'atkan (Jakarta: Departemen Agama RI 2008), h. 87. 


\section{E. Sistem Pengelolaan Zakat}

Sesuai dengan tuntutan Undang-undang RI Nomor 38 Tahun 1999 tentang Pengelolaan Zakat, bahwa pengelolaan zakat dilakukan oleh Badan Amil Zakat, baik tingkat nasional maupun tingkat daerah. Pemerintah tidak melakukan pengelolaan zakat, tetapi berfungsi sebagai fasilitator, koordinator, motivator dan regulator bagi pengelolaan zakat yang dilakukan oleh Badan Amil Zakat. ${ }^{12}$ Zakat sebagai rukun Islam merupakan kewajiban setiap muslim yang mampu untuk membayarnya dan diperuntukkan bagi mereka yang berhak menerimanya. Dengan pengelola yang baik, zakat merupakan sumber dana potensial yang dapat dimanfaatkan untuk memajukan kesejahteraan umum bagi seluruh masyarakat.

Agar menjadi sumber dana yang dapat dimanfaatkan bagi kesejahteraan masyarakat terutama untuk mengentaskan masyarakat dari kemiskinan dan menghilangkan kesenjangan sosial, perlu adanya pengelolaan zakat secara professional dan bertanggung jawab yang dilakukan oleh masyarakat bersama pemerintah. Dalam hal ini pemerintah berkewajiban memberikan perlindungan, pembinaan dan pelayanan kepada muzakk, mustahiq, dan pengelola zakat.

Tujuan pengelolaan zakat adalah untuk meningkatkan kesadaran masyarakat dalam penunaian dan dalam pelayanan ibadah zakat, meningkatkan fungsi dan peranan pranata keagamaan dalam upaya perencanaan, pengorganisasian, pelaksanaan, dan pengawasan agar menjadi pedoman bagi muzakki dan mustahiq, baik perseorangan maupun badan hukum dan/atau badan usaha. ${ }^{13}$ Dengan demikian, maka harapan peneliti dengan adanya sistem yang mengatur masalah pengelolaan zakat, maka diharapkan dapat meningkatkan pengelolaan zakat itu sendiri sehingga dapat berdaya dan berhasil guna untuk kesejahteraan masyarakat muslim diseluruh dunia.

${ }^{12}$ Departemen Agama, Pedoman Pengelolaan Zakat, (Jakarta: Departeman Agama, 2003), h. 30.

13 Departemen Agama, "Undang-undang RI Nomor 38 Tahun 1999 Tentang Pengelolaan Zakat dan Keputusan Menteri Agama RI Nomor 373 Tahun 2003 Tentang Pelaksanaan Undang-undang Nomor 38 Tahun 1999 Tentang Pengelolaan Zakat", (Jakarta: 2001), h.13-14. 


\section{F. Esensi Zakat Terhadap Pemberi dan Penerima}

Pengaruh Zakat Bagi Pemberi: ${ }^{14}$

a) Menghilangkan sifat kikir, danmendorong sikap murah tangan.

b) Mendekatkan para mukmin kepada Tuhan dan sadar bahwa kebahagiaan diperoleh dengan jalan menafkahkan hartanya di jalan Allah SWT..

c) Mendorong para mukmin menyempurnakan tauhidnya dan syahadatnya.

d) Mendorong hamba mensyukuri Allah yang telah memberikan harta.

e) Memalingkan jiwa dari jalan yang gelap kepada jalan yang terang.

f) Mengurangi sifat tamak

g) Menghiaskan diri dengan suatu perangai Allah, yaitu melimpahkan kebajikan dan rahmat kepada orang yang memerlukan.

h) Menjaga diri agar tidak tamak terhadap yang lebih rendah, dan yang lebih tinggi.

i)Mengalihkan orang kaya dari satu keutamaan kepada keutamaan yang lain.

j)Menjamin harta agar tidak hilang secara sia-sia.

k) Membentangkan harta dan menyuburkannya.

1)Menolak gangguan. Para fakir yang memperoleh zakat para hartawan, tergerak hatinya untuk memberikan bantuan-bantuan yang diperlukan dan melindungi para hartawan dari berbagai macam gangguan.

m) Memenuhi tugas yang diwajibkan Tuhan.

\section{G. Dampak Zakat Terhadap si Pemberi dan si Penerima}

Dampak zakat terhadap si pemberi dan si penerima adalah, pertama, mendorong orangorang mukmin, orang-orang kaya dan fakir untuk menyempurnakan kedua aspek, iman, sabar, dan syukur.

Harta sebagai barang yang disukai bila diperoleh mewajibkan syukur dan bila hilang, mewajibkan sabar. Dengan zakat, para fuqara mensyukuri nikmat yang mereka peroleh sedang para hartawan memperlihatkan kesabarannya arena sebagian hartnya berkurang.

Kedua, memastikan masing-masing mereka memberi nikmat kepada orang lain yang menghasilkan kebahagiaan bagi mereka itu. Orang kaya dengan memmberi zakat berarti

\footnotetext{
${ }^{14}$ Tengku Muhammad Hasbi Ash-Shiddeeqy, Kuliah Ibadah (Semarang: Pustaka Rizki Putra 2010), h. 178-
} 180. 
memberikan nikmat kepada orang fakir. Orang fakir dengan menerima zakat suatu syukur dari harta Allah yang dipertaruhkan dalam bendahara orang kaya, berarti memberi nikmat kepada orang kaya, melepaskan orang kaya dari sifat kikir, keaiban dunia, dan azab hari akhirat. Ini adalah suatu nikmat.

Ketiga, memberikan kebaikan kepada pemberi dan penerima. Allah tidak menjadikan harta karena mengingat dzatnya harta. Harta dijadikan untuk diambil manfaat. ${ }^{15}$

\section{Hasil Penelitian dan Pembahasan}

\section{A. Pemahaman Muzakki Masjid Al-Magfirah Kelurahan Karame Tentang Zakat Maal}

Zakat maal berarti mensucikan harta yang menumpuk yang wajib dikeluarkan, dengan syarat cukup nishab dan haul (setahun dimiliki), atau sesuai kadar/ukuran yang diambil dari kekayaan dan wajib diberikan kepada golongan tertentu.

Zakat juga merupakan manifestasi dari kegotong royongan antara orang kaya dengan fakir miskin. Pemberdayaan zakat merupakan perlindungan bagi masyarakat dari bencana kemasyarakatan, yaitu kemiskinan, kelemahan baik fisik maupun mental. Lembaga zakat merupakan sarana distribusi kekayaan dalam ajaran Islam yang merupakan kewajiban kolektif perekonomian umat Islam. Zakat merupakan komitmen seorang muslim dalam bidang sosialekonomi yang tidak terhindarkan untuk memenuhi kebutuhan pokok bagi semua orang, tanpa harus meletakkan beban pada kas negara semata.

Pemahaman (comprehension) dalam penelitian ini adalah bagaimana seorang mempertahankan, membedakan, menduga (estimates), menerangkan, memperluas, menyimpulkan, mengeneralisasikan, memberikan contoh, menuliskan kembali, dan memperkirakan. ${ }^{16}$

Dengan menggunakan teori-teori di atas, penulis berusaha menjawab pertanyaan tulisan ini. Gambaran pemahaman muzakki masjid Al-magfirah mengenai zakat maal, bisa digambarkan dalam kutipan hasil wawacara peneliti dengan informan sebagai berikut:

${ }^{15}$ Ibid., h. 180-181.

16 Suharsimi Arikunto. Dasar - Dasar Evaluasi Pendidikan (edisi revisi), Cet. IX (Jakarta: Bumi Aksara,2009), h. 118 - 137. 
Zubair Ladiku mengatakan: "Zakat maal itu untuk pembangunan rumah ibadah, sekolah yang diberikan jam'aah sesuai, zakat fitrah diberikan orang semenjak lahir, zakat maal artinya maal ini zakat harta. Jenis harta dizakat maal banyak yang wajib dizakati bahan bangunan, tanah apa saja yang termasuk dalam pembangunan itu adalah zakat maal. Mustahik delapan golongan, yang wajib mengeluarkan zakat kalau zakat fitrah wajib zakat maal terbatas siapa yang mempunyai kemampuan mengeluarkan. Kadar zakat maal itu $1 \frac{112 \% " .17}{17}$

Sebuah jawaban yang menunjukkan bahwa muzakki belum memahami zakat maal secara komprehensif dan belum melaksanakan sesuai dengan ketentuan fikih.

Sandra Arsyad: "Zakat maal itu harta yang berlebihan, beda zakat maal dan zakat fitrah itu kalau zakat maal untuk harta sedangakn zakat fitrah itu untuk sucikan diri, jenis harta yang wajib dizakatkan itu rumah, mobil, dan emas. Golongan orang yang dapat zakat janda, anak yatim, dan muallaf, sedangkan kriteria yang wajib mengeluarkan zakat maal itu adalah orang mampu dan ukuran zakat maal yang di keluarkan 2,4\%”. Peran amil zakat sangat bagus". ${ }^{18}$

Jawaban responden (muzakki) diatas semakin menunjukkan kurangnya tingkat pemahaman mengenai zakat maal. Hal ini mengindikasikan kurang maksimalnya pembelajaran tentang arti pentingnya zakat bagi kesejateraan umat.

Fatma Abudji: "Tidak tahu itu zakat maal apa, jenis harta yang dikeluarkan itu emas, tanah, gedung pokoknya yang bisa bermanfaat, orang yang wajib menerima zakat itu janda, anak yatim dengan muallaf. Orang yang wajib mengeluarkan zakat kalau dia mampu, ada mobil, dan emas, syarat mengeluarkan zakat maal tidak tahu". ${ }^{19}$

Pemahaman yang masih kurang sehingga zakat maal yang dikeluarkan oleh muzakki tidak sesuai dengan kaidah fikih. Solusi bagi hal ini adalah pembelanjaran rukun Iman dan rukun Islam harus lebih di tingkatkan bagi muzakki masjid Al-Magfirah. Ini merupakan salah satu kewajiban bagi Badan Keimamam dan Badan Ta'mir Masjid Al-Magfirah.

\footnotetext{
${ }^{17}$ Hasil wawancara dengan Bapak Zubair Ladiku, tanggal 18 Oktober 2013.

${ }^{18}$ Hasil wawancara dengan Bapak Ibu Sandra Arsad, tanggal 20 Oktober 2013.

${ }^{19}$ Hasil wawancara dengan Ibu Fatma Abudji, tanggal 21 Oktober 2013.
} 
Ridwan Madjid: "Menurut saya zakat maal itu zakat harta. Beda zakat maal mensucikan harta dan zakat fitrah mensucikan diri, jenis harta emas, mobil yang dipakai untuk mancari, pendapatan atau gaji. Golongan yang wajib menerima ada 8 golongan yaitu yatim, piatu, fakir, miskin, amil, muallaf, dan janda. Yang mampu mengeluarkan zakat maal itu orang yang mampu. Kadar zakat binatang 16-20 ekor atau sesuai pendapatan. Kalau om iwan kase kaluar zakat sesuai dengan pendapatan kalau ada lebe kase kaluar". ${ }^{20}$ Ungkapan pengetahuan dan kesadaran akan pentingnya zakat untuk yang kurang mampu tetapi belum memahami kadar zakat maal yang akan dikeluarkan. Pengetahuan tentang zakat masih sangat kurang, sehingga antara syarat dan rukun, sunnah dan wajib, nisab dan haul, masih tidak dapat dibedakan.

Amu Dama: "Nintau apa itu zakat maal, zakat fitrah itu zakat mensucikan diri dari dosa, jenis harta oto, motor, dan tanah, orang yang wajib menerima zakat maal itu janda, miskin, anak yatim piatu, syarat kase kaluar zakat maal itu kalau mampu, ukuran zakat maal itu 2,5\%". Karena kesibukan zakat maal kalau mokase setiap hari minggu untuk pembangunan masjid'. ${ }^{21}$

Kesadaran untuk mengeluarkan zakat maal tidak ada dikarenakan pada kesibukan sehingga pemahaman zakat maal hanya berupa infak atau pun sedekah.

Hj. Dolly Panu: "Zakat maal harta semua yang ada di dalam rumah, zakat fitrah itu zakat harta. Jenis harta yang dizakati emas. 8 golongan yang wajib menerima zakat janda, yatim piatu, dhuafa. Orang yang wajib mengeluarkan zakat orang yang mampu, kadar zakat maal kalau dari harta tetap 2,5\%". ${ }^{22}$

Hasil temuan dilapangan menunjukkan kurangnya tingkat pemahaman muzakki yang sudah melaksanakan rukun Islam ke lima (Haji). Walaupun sudah melaksanakan ibadah haji, belum menjamin seseorang sudah memahami islam secara kaffah. Hal ini mengakibatkan semakin banyak tantangan yang harus di hadapi oleh Unit Pengumpul Zakat, agar supaya zakat

\footnotetext{
${ }^{20}$ Hasil wawancara dengan Bapak Ridwan Madjid, tanggal 21 Oktober 2013.

${ }^{21}$ Hasil wawancara dengan Ibu Amu Dama, tanggal 4 November 2013.

${ }^{22}$ Hasil wawancara dengan Ibu Hj. Dolly Panu, tanggal 4 November 2013.
} 
maal bisa terkmpul secara maksimal sehingga bisa berpengaruh dalam peningkatan kesejahteraan umat.

Yusuf Piu: "Zakat maal itu zakat harta, zakat fitrah itu zakat diri. Jenis harta yang dizakati emas perak, beras, uang. 8 golongan yang wajib menerima zakat fakir, miskin, amil, dan muallaf . Orang yang wajib mengeluarkan zakat orang yang mampu, kadar zakat maal 2,5\%". Om usu kase kaluar zakat maal itu setiap hari minggu, kase doi untuk pembangunan masjid. Om usu tau zakat maal itu dari ceramah agama dari TV dan baca buku kunci ibadah. ${ }^{23}$

Gambaran di atas menunjukkan pemahaman yang tidak tepat mengenai zakat maal. Sebagai perbandingan, menurut kaidah fikih, cara menghitung zakat maal adalah sebagai berikut:

Zakat maal $=2,5 \% \mathrm{x}$ jumlah harta yang tersimpan selama 1 Tahun (Tabungan dan Investasi). Menghitung nisab zakat maal $=85 \mathrm{x}$ harga emas pasaran per gram.

Contohnya : seseorang mempunyai harta yaitu tabungan di Bank 100 juta rupiah, deposito sebesar 200 juta rupiah, rumah kedua yang dikontrakkan senilai 500 juta rupiah dan emas perak senilai 200 juta. Total harta yakni 1 Miliyar rupiah. Semua harta sudah dimiliki sejak satu tahun yang lalu.

Jika harga 1 gram emas sebesar Rp. 250.000,- maka batas nisab zakat maal adalah Rp. 21.250.000,- (85 gram x 250.000). Karena harta seseorang itu sudah lebih dari limit nasib, maka ia harus membayar zakat maal sebesar Rp. 1 miliyar x 2,5\% = 25 juta rupiah per tahun.

Maryam Pakaya: "Nintau zakat maal itu sumbangan-sumbangan sama dengan emplop jaga kase bajalang bulan puasa, zakat fitrah itu zakat pembersihan diri. Jenis harta yang wajib dizakati itu beras, uang. Orang yang wajib dapat zakat maal janda, anak yatim. Yang wajib mengeluarkan zakat itu hanya orang mampu, kadar zakat maal 3\% dari harta yang dapa". ${ }^{24}$

Ketidak pahaman muzakki akan zakat maal terutama yang, mengakibatkan pengumpulan dan penerimaan zakat maal tidak maksimal. Akibat akhirnya adalah tujuan zakat maal yang

\footnotetext{
${ }^{23}$ Hasil wawancara dengan Bapak Yusuf Piu, tanggal 4 November 2013.

${ }^{24}$ Hasil wawancara dengan Ibu Maryam Pakaya, tanggal 7 November 2013
} 
diamanahkan oleh ajaran Islam tidak tercapai. Hal ini berarti peningkatan kesejahteraan umat tidak tercapai, pemberantasan kemiskinan umat tertunda, dan semakin nyata gap antara yang miskin dan yang kaya. Pemerataan pendapatan yang tidak merata. Akhirnya jumlah fakir dan miskin akan semakin bertambah dari tahun ke tahun dan mustahik akan berkurang.

Beberapa muzakki mengeluarkan zakat maal hanya satu tahun sekali yaitu pada pertengahan bulan Ramadhan. ${ }^{25}$ Itu pun digabung dengan infak dan sedekah, hal ini dapat dilihat pada laporan penerimaan dan penyaluran zakat muzakki masjid Al Maghfirah Karame tahun 2011 sampai dengan 2013 (terlampir). Menurut Imam masjid laporan ini di serahkan kepada Kepala KUA (Kantor Urusan Agama) minimal seminggu setelah selesai lebaran. ${ }^{26}$

Adapun beberapa hal yang menyebabkan Muzakki masjid Al-Magfirah Kelurahan Karame kurang paham mengenai zakat maal, yaitu sebagai berikut:

1. Tidak ada sosialisasi dari Badan Amil Zakat tentang zakat maal kepada muzakki masjid.

2. Kurangnya perhatian pemerintah dalam hal menumbuh kembangkan pengetahuan masyarakat dibidang zakat, khususnya zakat maal, padahal banyak masyarakat Kelurahan Karame khususnya muzakki masjid Al-Magfirah yang telah memenuhi syarat sebagai orang yang wajib mengeluarkan zakat maal.

3. Kurangnya keinginan Muzakki masjid Al-Magfirah dalam mencari referensi yang berhubungan zakat maal, sehingga zakat maal terkesan sama dengan sedekah dan infak.

\section{B. Pemahaman Muzakki Masjid Al-Magfirah Dalam Meningkatkan Penerimaan Zakat Maal}

Jumlah zakat maal yang seharusnya di keluarkan menurut syariat Islam adalah 2,5\% dari harta yang didapat. Hal ini merupakan keadilan yang diajarkan oleh Islam dan prinsip keringanan yang terdapat di dalam ajaran-ajarannya tidak mungkin akan membebani orang-orang yang terkena kewajiban itu melaksanakannya kedalam kesulitan yang oleh Tuhan sendiri tidak

\footnotetext{
${ }^{25}$ Hasil wawancara dengan Imam masjid Al-Magfirah Kelurahan Karame, tanggal 2 Oktober 2013.

${ }^{26}$ Hasil wawancara dengan Imam masjid Al-Magfirah, tanggal 4 oktoer 2013.
} 
inginkan. oleh karena itu mestilah batasan tentang sifat kekayaan yang wajib zakat dan syaratsyaratnya:

1. Milik penuh

2. Cukup nisab

3. Lebih dari kebutuhan biasa

4. Bebas dari hutang

5. Berlalu setahun.

Kenyataan dilapangan 8 orang yang wajib mengeluarkan zakat maal. Tapi hanya 2 orang yang mengeluarkanya. ${ }^{27} \mathrm{Hal}$ ini sangat berpengaruh pada peningkatan penerimaan zakat maal untuk kesejahteraan muzakki yang kurang mampu di tambah pengumpulan zakat maal di kumpulkan setahun sekali pada pertengahan bulan ramadhan.

Menurut catatan Amil zakat masjid Al-Magfirah Kelurahan Karame, potensi zakat hanya mencapai 1 juta - 2,5 juta per tahun dan itu belum sepenuhnya terserap.

Kenyataan saat ini, zakat yang diterima badan amil zakat bukan hanya disebabkan rendahnya pengetahuan agama muzakki masjid, tetapi juga dikarenakan rendahnya kepercayaan masyarakat terhadap badan Amil zakat. Dalam hal ini sebagian muzakki yang mampu untuk mengeluarkan zakat maal lebih condong mengeluarkan zakat langsung kepada seseorang yang menurutnya berhak menerima. ${ }^{28}$

\section{Sistem Pengelolaan Zakat Maal Masjid Al-Magfirah}

Amil zakat adalah salah satu pelaku zakat yang bertindak sebagai tim atau Organisasi Pelaksana Zakat. Tim inilah yang secara langsung menangani pelaksanaan amaliah zakat. Secara organisatoris, amil zakat ini merupakan sebuah organisasi yang ditunjuk atau dibentuk oleh ulul amri. Lebih baik lagi apabila Organisasi Amil Zakat ini dibentuk secara nasional, sehingga sistem pengawasannya lebih memudahkan, baik pengawasan langsung dari pihak ulul amri sendiri maupun pengawasan tidak langsung dari segenap umat muslim di wilayah kerjanya masing-masing.

Organisasi Amil Zakat perlu dibentuk secara struktural, mulai dari tingkat pusat, tingkat daerah, sampai ketingkat yang paling kecil. Masing-masing tingkat tidak terlepas dari koordinasi

\footnotetext{
${ }^{27}$ Hasil wawancara dengan Imam masjid Al-Magfirah, tanggal 2 Oktober 2013.

${ }^{28}$ Hasil wawancara dengan sekertaris Amil zakat Bapak Udin Latara, tanggal 20 Oktober 2013.
} 
dengan pihak ulul amri setempat, meskipun garis kerjanya tetap sesuai dengan apa yang digariskan oleh Organisasi Amil Zakat tingkat pusat. ${ }^{29}$

Dengan demikian peneliti melihat bahwasanya sistem pengamalan zakat ini tidak bisa dianggap enteng. Apabila hanya dikerjakan setengah-setengah pastilah hasilnya sangat minim dan tidak Nampak sama sekali. Dan akhirnya, bisa-bisa syariat zakat itu hanya dianggap ada dalam Al-Qur'an dan Hadits semata atau sebagai pelengkap rukun Islam belaka.

Menurut penjelasan UU Nomor 38 tahun 1999 tentang pengelolaan zakat Tujuan pengelolaan zakat adalah meningkatnya kesadaran masyarakat dalam penunaian dan dalam pelayanan ibadah zakat, meningkatnya fungsi dan perananan pranata keagamaan dalam upaya mewujudkan kesejahteraan masyarakat dan keadilan sosial, serta meningkatnya hasi guna dan daya guna zakat.

Adapun menurut UU Nomor 38 Tahun 1999 pada pasal 8 tugas dari Badan Amil Zakat adalah mengumpulkan, mendistribusikan dan mendayagunakan zakat sesuai dengan ketentuan agama.

Pada kenyataan dilapangan penulis menemukan pengelolaan dan tugas dari Amil zakat masjid Al-Magfirah tidak sesuai dengan UU yang berlaku. Hal ini juga berpengaruh terhadap peningkatan penerimaan zakat maal.

\section{Kesimpulan}

Berdasarkan Pengelolaan data dan hasil analisis penulis yang mengacu pada masalah dan tujuan penelitian, maka dapat disimpulkan sebagai berikut:

1. Penulis menyimpulkan bahwa, muzakki masjid Al-Magfirah Kelurahan Karame belum memahami apa yang disebut zakat maal. Karena dari 8 orang yang wajib mengeluarkan zakat hanya 2 Orang mengeluarkan zakat maal itupun tidak sesuai dengan jenis harta apa yang dikeluarkan. Beberapa sebagian besar informan berpendapat zakat maal itu zakat pembersihan jiwa, zakat fitrah pembersihan diri, dan zakat maal sama dengan infak maupun sedekah, serta 8 golongan janda, anak yatim, fakir, miskin, amil, dan muallaf.

\footnotetext{
${ }^{29}$ M. Nipan Abdul Halim, M engapa Zakat D isyari'atkan (Jakarta: Departemen Agama RI, 2008), h. 87-90.
} 
2. Berdasarkan hasil penelitian zakat maal belum terkelola dengan baik oleh UPZ (Unit Pengumpulan Zakat), karena pemahaman muzakki masjid Al-Magfirah masih kurang, oleh karena muzakki masjid menyamakan zakat maal dengan infak dan sedekah sehingga penerimaan zakat maal sangat sedikit ditambah lagi dengan pencampur adukkan zakat maal, infak dan sedekah menyebabkan penerimaan zakat maal, infak dan sedekah tidak dapat dibedakan. 


\section{Daftar Pustaka}

Al-Albani Nashirudin Muhammad, Ringkasan Shahih Muslim (Jakarta: Pustaka Azzam anggota IKAPIDKI,2003)

Departeman Agama Republik Indonesia, al-Qur'an dan Terjemahanny, (Jakarta:P CV.Kathoda, 2005)

Departemen Agama, Pedoman Pengelolaan Zakat (Jakarta: Departemen Agama, 2003)

Direktorat Jendral Pemberdayaan Pembinaan Kelembagaan agama Islam Departemen Agama, Ilmu Fiqh Jilid I (Jakarta: Proyek Pembinaan Prasarana da Sarana Perguruan Tinggi Agama, 1985)

Departemen Agama, "U ndang-undang RI Nomor 38 Tahun 1999 Tentang Pengelolaan Zakat dan Keputusan Menteri Agama RI Nomor 38 Tahun 1999 Tentang Pelaksanaan Undangundang Nomor 373 Tahun 2003 Tentang Pengelolaan Zakat" (Departemen Agama, Jakarta, 2001)

Departemen Pendidikan Nasional, Kamus Besar Bahasa Indonesia, edisi 2 (Jakarta: Balai Pustaka, 1994)

Ja'far, Muhammadiyah, Tuntunan Ibadah Zakat Puasa dan Haji, Cet. V (Jakarta: Kalam Mulia, 2005)

Kelurahan Karame, Laporan Kegiatan Pemerintah, Pembangunan, dan Kemasarakatan (Manado: Kelurahan Karame, 2007)

Kementrian Agama Republik Indonesia, Fiqih Zakat (Jakarta: 2010)

Khasanah, Umrotul, Manajemen Zakat Modern (Malang: UIN Maliki Press, 2010)

M. Nipan Abdul Halim, M engapa Zakat D isyari'atkan (Jakarta: Departemen Agama RI, 2008)

Maleong, Lexi J, Metode Penelitian Kualitatif, Cet. IX (Bandung: Remaja Rosdakarya, 2000)

Maleong, Lexi J, Metode Penelitian Kualitatif (Bandung: Remaja Rosadakarya, 2001)

Manan, M.A., Islamic Economics: Theory and Practice, terj. Potan Arif Harahap dengan judul Ekonomi Islam: Teori dan Praktek (Jakarta: Intermasa, 1992)

Mas'ud Ridwan, Muhammad, Zakat \& Kemiskinan (Yogyakarta: UII Press, 2005)

Muhammad Jawad Mushniyah, Al Fiqh'ala Al - Mazhab Al - al Khamsah, terj. Afif Muhammad, Idrus Al - Khaf judul Fiqh Lima Mazhab, Cet. XI (Jakarta: Lentera Basri Tama. 2004)

Nana S. Sukmadinata, Metode Penelitian Pendidikan (Bandung: PT. Remaja Rosada Karya, 2006)

Nasir, Moh, Metode Penelitian, Cet. IV (Jakarta: Graha Indonesia, 1999)

Nasution, Metode Penelitian Kualitatif (Bandung: Jemars, 1998)

Nata, Abudin, Paradigma Pendidikan Islam (Jakarta: PT Grasindo, 2001)

Qardawi, Yusuf, Fiqhuz Zakat, terj. Salman Harun dan Didin Hafidnuddin, Hukum Zakat: Studi Komparatif Mengenai Status dan Filsafat Zakat berdasarkan Qur'an dan Hadis (Bandung: Mizan, 1999) 
Rafiq, Ahmad, Fiqh Kontekstual (Semarang: Pustaka Pelajar Offset, 2004)

Shiddiqy-Ash, Tengku Muhammad Hasbi, Kuliah Ibadah (Semarang: Pustaka Rizki Putra, 2010)

Sudjana, Nana dan Ibrahim R., Penelitian dan Penilaian Pendidikan (Bandung: Sinar Baru Algen Sind, 1989)

Sugiyono, Metode Penelitian Kombinasi Mix Methods, Cet. IV (Bandung: Alfabeta, 2013)

Suprayogo, Imam, Metodologi Peneltian Sosial Agama (Bandung: Rosdakarya, 2006)

Zuhaili, Wahbah, Al-Fiqhu Asy-Syafi'i Al-Muyassar, terj. Muhammad Afifi dan Abdul Hafiz, Fiqh Imam Syafi'I (Jakarta: Almahira, 2010) 